Much of his work, it must be admitted, was somewhat slipshod and much of it "scissors and paste." But his Handbook, Illustrations, Mycographia, and Grevillea, together with his efforts to popularize the study of fungi, enable us to realize his place in Mycology.

I am indebted to Miss Leila A. Cooke for her kind assistance in many ways.

\title{
WILLLIAM LEIGH WILLIAMSON EYRE.
}

$$
\begin{gathered}
(184 \mathrm{I}-1914 .) \\
\text { By J. Ramsbottom, M.A. }
\end{gathered}
$$

The British Mycological Society has suffered a great loss through the death, on October 25 th, I9I4, of the Rev. W. L. W. Eyre, one of its most loyal members. Mr. Eyre was born at Padbury, Bucks, on March I 7 th, I841. Educated for the merchant service, he went to sea at an early age, but gave up sea-faring to enter Lichfield College as a theological student. He was ordained deacon in 1865 and priest in 1866 , in Lichfield Diocese. His first curacy was at Sheriff Hales, Staffordshire, 1865-8. Afterwards he was curate of West Dean, Wilts., I868-70; of Huntley, Gloucester, I870-72; and Northchurch, Hertfordshire, $1872-5$. In 1875 he was appointed rector of Swarraton and vicar of Northington, Hants, by the then Lord Ashburton. Mr. Eyre early took up the study of fungi, and was a member of the Woolhope Club during the later years of its mycological activities. When the British Mycological Society was formed in 1896 , he at once became one of its most enthusiastic members, and up to the time of his death took the greatest possible interest in everything that affected the Society. For a number of years he most generously provided the Transactions with a coloured plate, realising the great necessity of such in the study of Basidiomycetes. For the season I 903 he was elected President, and gave as his address "Mycology as an instrument of recreation." The only other paper he wrote for the Transactions is "Notes on Hants Fungi" (1899), a most suggestive paper giving his experiences as to the relation of certain fungi to edaphic conditions. $\mathrm{He}$ was responsible for the list of Hampshire fungi in the Victoria County History, and in 1907 published " A list of the fungi of the Grange Park and neighbourhood, Hampshire." The repu- 
tation he held amongst Mycologists was that of doing most careful field work, in which he was always encountering rare or new agarics. His attention was not, however, restricted to these, but any microfungi which seemed sufficiently distinct he forwarded to the one of his many mycological friends whom he thought it would most interest. He gave great assistance to M. C. Cooke in the preparation of his Illustrations by providing him with many rare species. After Dr. Cooke's retirement the new finds were sent to Mr. G. Massee, but since the foundation of the British Mycological Society they have been named or described by Mr. Carleton Rea and by Miss Lorrain Smith. A glance through the past volumes of the Transactions will reveal the large number of new records which are due to Mr. Eyre's activities. Many of these, and all the new species, have been illustrated in the Transactions by Mrs. Rea. $\mathrm{He}$ commemorated his happy hunting grounds in naming a fungus he described Schulzeria Grangei, but apart from this he appears to have been well-content to send the plants which he had exhaustively examined to a recognised authority for determination or description. $\mathrm{He}$ was an ardent Naturalist, and was a member of the Hampshire Field Club from its formation, publishing several papers, principally on fungi, in the Papers and Proceedings of the Club. For many years he made a close study of the genus $R u b u s$, and his collection, together with that of the Mycetozoa, is in the Educational Museum at Haslemere. $\mathrm{He}$ was also interested in land and freshwater shells and made a very complete collection of those occurring in North Hampshire. Mosses and archæology also claimed part of his attention-and he wrote a history of the parish of which he was vicar for so many years. He was a fellow of the Royal Meteorological Society and for a long period kept tabulated records of the district round Swarraton. The illness which preceded his death was long and painful. During the last few years Mr. Eyre rarely attended the meetings of the Society. The photograph of the first Haslemere meeting (1905), published in this number, shows Mr. Eyre as he was best known to the members, and in addition the group includes many of the past presidents and older members to whom the Society has been so much indebted in the past.

Mr. Eyre's geniality (which seemed to have a trace of the sea), his great enthusiasm, his wide outlook on Nature, and his generosity will be much missed amongst his many friends.

The species Chlorospora Eyrei Mass. and Sebacina (Bourdotia) Eyrei Wakefield* have been named in his honour.

I am much indebted to Miss Eyre for her kindness in supplying me with information.

$$
\text { * Cf. } \mathbf{p} \cdot \mathbf{1 2 6 .}
$$

Published roth May, I9I5. 


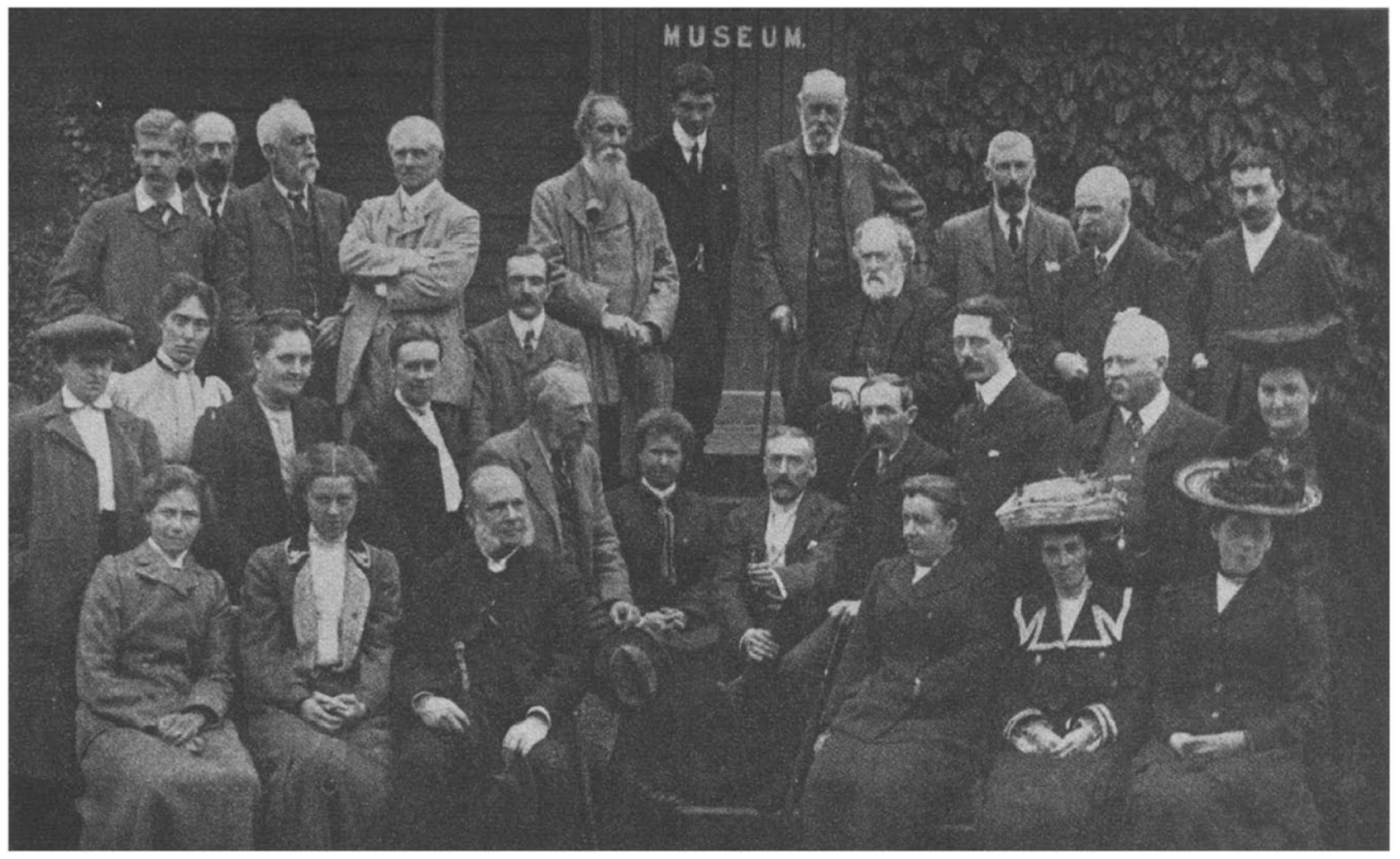

J. Eyre. A. Fry. A. Lorrain Smith. Gulielma Lister. C. B. Plowright. Mrs. E. A. Rea. C. Rea. R. H. Biffen (President). G. C. Hughes. C. P. Bird. Mrs. Bird. Mrs. A. Montague. E. Plowright. W. L. W. Eyre.

Mrs. Biffen.

Mrs. Swanton.

M. K. Spittal.

The British Mycological Society. Haslemere Foray, 25th to 30th September, 1905. 